\title{
Family Medicine from the First to the Sixth Year of Undergraduate Medical Training: Considerations on an Educational Proposal for School-Service Curricular Integration
}

\author{
Medicina de Família do Primeiro ao Sexto Ano \\ da Graduação Médica: Considerações sobre uma \\ Proposta Educacional de Integração Curricular \\ Escola-Serviço
} Martim Elviro de Medeiros Junior ${ }^{I}$ Paulo de Nogueira Fontão Haraldo Cesar Saletti Filho ${ }^{I}$ Pedro Félix Vital Junior Monique Marie Marthe Bourget ${ }^{I}$ Izabel Cristina Rios ${ }^{I, I}$

\section{KEY-WORDS}

- Medical Education.

- Educational Models.

- Learning.

- Family Practice.

- Primary Health Care.
I Santa Marcelina Faculty, São Paulo, SP, Brazil.

II University of São Paulo, São Paulo, SP, Brazil.

\begin{abstract}
Medical training is current topic of discussion both on the national and international stage due to changes in contemporary society and the consequent health demands. In Brazil, insertion into the workplace of the Primary Health Care (PHC) student is recommended throughout the medical course. However, such insertion is hampered by inadequate practical scenarios, the lack of preceptors, insufficient training of general practitioners to receive students, teachers without adequate training in teaching in the area and resistance by teachers of traditional disciplines. This article describes and analyzes a model for insertion into PHC and Family and Community Medicine (FCM) of students from a medical course in São Paulo, the challenges of teaching-management integration and the actions that help to address these issues. The proposal is based on educational objectives aimed at developing competences (knowledge, skills and attitudes) so that the student can offer comprehensive care, understanding the individual in the context of family, social and environmental life. The program contents were developed to provide learning in an increasing degree of complexity, connecting previous knowledge to new knowledge. From this starting point, the development of the educational project has as innovative brand involving a combination of planning and educational management that adopts the following measures to improve the quality of the teaching-learning process: (1) insertion of students into Basic Health Units (BHU) from the first year to internship; (2) hiring family doctors as faculty staff; (3) integration of the contents of the Family Medicine and PHC modules with the contents of other disciplines, such as Epidemiology, Health Policies and Evidence-Based Medicine; (4) critically questioning teaching methodologies regarding their suitability for the topic addressed and the student and teacher profiles; (5) formative assessments; (6) pedagogical improvement for teachers and preceptors for the exercise of teaching in health; (7) practices that encourage students to work in interprofessional teams; (8) encouragement of national and international exchange programs for undergraduate and residency students in FCM; (9) promotion of the publication of books, articles and research in PHC. Among the facilitating factors for the good progress of this teaching proposal, it is highlighted that FCM and PHC are the axial foundations of the political-pedagogical project of the medical course and are developed in an institution that has a long history of assistance and teaching in the health area, contributing significantly to service-school integration. Dialogue is required for the execution of didactic activities in the practical settings, due to the proximity between local management, preceptors and teacher-managers. Another factor which strengthens the proposal is the investment in the preceptor team through training, participation in the construction and integration of content proposed in the FCM modules and a human resources policy that values them. Thus, it is considered that the presentation of this initiative could contribute to the debate on educational models for curricular insertion into FCM and PHC, and the related challenges and possibilities in contemporary medical education.
\end{abstract}




\section{PALAVRAS-CHAVE}

- Educação Médica.

- Modelos Educacionais

- Aprendizagem.

- Medicina de Família e

Comunidade.

- Atenção Primária à Saúde.

Received in: 11/11/2016

Approved in: 11/18/2016

\section{RESUMO}

Em contexto nacional e internacional, discute-se a formação médica devido às mudanças na sociedade contemporânea e suas demandas de saúde. No Brasil, preconiza-se a inserção do aluno na Atenção Primária à Saúde (APS) durante todo o curso médico. Tal inserção é dificultada pelos cenários práticos inadequados, pela falta de preceptores, pela formação insuficiente dos médicos generalistas para receber estudantes, pelos docentes sem capacitação adequada para o ensino na área e pela resistência de docentes de disciplinas tradicionais. Este artigo descreve e analisa um modelo de inserção da APS e Medicina de Família e Comunidade (MFC) em um curso médico no município de São Paulo, os desafios da articulação ensino-gestão e as ações que ajudam a enfrentá-los. A proposta parte de objetivos educacionais que visam desenvolver competências (conhecimentos, habilidades e atitudes) para que o aluno possa oferecer cuidado integral, compreendendo o indivíduo no contexto de vida familiar, social e ambiental. Os conteúdos programáticos foram desenvolvidos para propiciar aprendizagem em grau crescente de complexidade, articulando saberes prévios com novos saberes. Deste ponto de partida, o desenvolvimento do projeto educacional tem como marca inovadora a combinação de planejamento e gestão educacional que adota as seguintes medidas para aprimorar a qualidade do processo ensino-aprendizagem: (1) inserção dos alunos em Unidades Básicas de Saúde (UBS) do primeiro ano ao internato; (2) contratação de médicos de família como docentes da faculdade; (3) integração dos conteúdos dos módulos de Medicina de Família e APS com os conteúdos de outras disciplinas, como Epidemiologia, Políticas de Saúde e Medicina Baseada em Evidências; (4) metodologias de ensino problematizadoras adequadas à temática abordada e ao perfil do estudante e do docente; (5) avaliações formativas; (6) aprimoramento pedagógico para docentes e preceptores para o exercício do ensino em saúde; (7) práticas que estimulem o aluno a trabalhar em equipes interprofissionais; (8) incentivo a programas de intercâmbio nacionais e internacionais para alunos de graduação e de residência em MFC; (9) fomento à publicação de livros, artigos e pesquisa em APS. Entre os fatores facilitadores para o bom andamento dessa proposta de ensino, ressalta-se o fato de que MFC e APS são fundamentos axiais do projeto político-pedagógico do curso médico e se desenvolvem em uma instituição que tem longa história de assistência e ensino na área da saúde, contribuindo fortemente para a integração serviço-escola. A interlocução necessária às atividades didáticas nos cenários de prática se dá pela proximidade entre gestão local, preceptores e gestores-docentes. Outro fator de fortalecimento da proposta é o investimento na equipe de preceptores por meio de capacitação, participação na construção e na integração de conteúdos propostos nos módulos de MFC e a política de recursos humanos que os valoriza. Assim, considera-se que a apresentação desta iniciativa poda contribuir para o debate de modelos educacionais para inserção curricular da MFC e APS, seus desafios e possibilidades na educação médica contemporânea.

\section{INTRODUCTION}

Teacher, what's the point of having health and family medicine station from the first to the sixth year? (graduation student)

Any hospital specialist, who has studied much more complex things, may be a family doctor... (professor of medicine)

Questions such as these, posed by teachers and medical students, reveal a cultural notion of Family Medicine marked by ignorance of the field and the curricular proposals of Primary Health Care (PHC) and Family and Community Medicine (FCM) in medical education. Traditionally centered in the hospital, medical education is under review in light of the changes in health care and training.
Over the last 40 years, Brazil has undergone a sociodemographic and epidemiological transition. The population grew from 94 million in 1970 to 191 million in 2010, and life expectancy at birth increased from 52.3 years in $1970^{1}$ to 75.2 years in 2015. New health problems have emerged, such as chronic diseases and mental disorders ${ }^{2}$, representing challenges for the Unified Health System (SUS). Faced with this socioeconomic, demographic and epidemiological scenario, medical schools began to discuss higher education in health in view of contemporary needs and to propose modifications to meet the demands of health and care.

For the medicine course, the proposed modifications in this regard were outlined in the National Curriculum Guidelines (NCG) of $2001^{3}$. They highlighted the need to adjust the medicine curricula, and seek to train doctors with a "humanistic, critical, reflective and ethical" view, capable of of- 
fering comprehensive, longitudinal care, and identifying the social factors that determine the health and disease process ${ }^{3}$. The Ministries of Health and Education created the Incentive Project for Curricular Changes in Medical Schools (Promed) with the aim of stimulating changes in medical courses and promoting the adaptation of professional training to meet to the needs of the SUS ${ }^{4}$. In 2014, the NCG review reaffirmed the need to adapt education to demands, outlining that:

the fundamental contents for undergraduate medical training must be related to the whole health-disease process of the citizen, the family and the community [...], providing the integrality of health care actions ${ }^{5}$. (p.10)

The proposal, therefore, suggested a methodological redesign that integrates practical Primary Care settings for the development of such content, including during internship. NCG 2014 advocates that at least 30\% of the internship workload is developed in PHC and Emergency/Urgent Care Service settings of the SUS 5 .

The NCG guidelines for modifications to the medical curricula, including the increased working hours in the PHC, are aligned to the recommendation proposed by the Brazilian Association of Medical Teaching (ABEM) and the Brazilian Society of Family and Community Medicine to insert PHC into medical education. This represented a shift in focus toward attaining comprehensive, longitudinal clinical practice, aimed at family and community health and based in the Basic Health Units. Furthermore, these organizations recommend that the insertion of PHC be continuous throughout the medical course $^{6}$.

Between the years 2000 and 2015, there was a significant increase in the number of medical courses in Brazil, mainly at private universities, which currently correspond to $60 \%$ of the total. In 2015, the number of medical schools in Brazil reached $266^{7}$. More than 24,000 doctors are trained every year. Most of the older schools and many of the new ones adopt curricula inspired by the flexnerian model (1910), supported by Biological Sciences, Chemistry and Physics, and practical training in hospitals and laboratories as the main teaching-learning scenarios ${ }^{8}$. Medical education on these bases has raised the scientific quality, but also resulted in a biomedical centrality that touches the health-disease process in the collective and family sphere, with limited scope in relation to the context of the patient's life and the social determinants of the health-disease process.

There are other factors related to the difficulties in implementing curricular modifications for the insertion of PHC and
FCM. These include, for example, teacher resistance against the implementation of a new model; insufficient teacher training for teaching in the work setting; and practical scenarios that do not favor the educational process, such as physically unsuitable BHU buildings, lack of preceptors and insufficient training of general practitioners to receive students ${ }^{9}$.

Against this backdrop, medical courses in Brazil have adapted in a heterogeneous manner to the modifications proposed by the NCG. In the national literature, we find few studies describing teaching-learning experiences in the PHC scenario $^{10-12}$. In particular, there are few scientific publications that describe and evaluate models of PHC insertion in the competency-based curriculum to be developed.

Faced with such difficulties and the proliferation of medical schools, it is essential to share initiatives for FCM and PHC curricular insertion, its educational management and teaching-service articulation. This article describes and analyzes a model for the insertion of PHC and FCM from the first to the last semester in the undergraduate medical course of the Santa Marcelina School of Medicine (FASM), as well presenting the challenges faced and the actions for teaching-management coordination executed to overcome those challenges.

\section{THE LOCAL CONTEXT}

The Santa Marcelina Health Complex (CSSM) has been operating in the eastern region of the city of São Paulo since 1961, when the Santa Marcelina Hospital was inaugurated. This region has 3,620,429 inhabitants and is characterized as an area of medium to high social vulnerability ${ }^{13}$.

Currently, CSSM manages three tertiary hospitals in the city of São Paulo (Itaquera, Itaim Paulista and Cidade Tiradentes) and 1,770 beds, of which 90 are beds in Intensive Care Units. The Itaquera hospital performs an average of 150,000 emergency room visits per year, 400,000 outpatient visits, 25,000 hospital admissions and 14,000 surgeries. In 1989, the Santa Marcelina Hospital received provisional accreditation for the medical residency programs of Internal Medicine, Surgical Clinic, Vascular Surgery, Orthopedics and Anesthesiology. It was officially recognized as a teaching hospital in 2004 and today offers 42 medical residency programs accredited by the Ministry of Education (MEC).

In addition to its activities in hospitals, CSSM has also operated in PHC services since 1996, initially through a partnership with the State government, in the Integral Quality in Health (Qualis) project, and currently, in partnership with the Municipal Health Secretariat of São Paulo, involving the management of 146 health services, which include: Basic Health Units, psychosocial care centers, home care teams, medical 
outpatient clinics and rehabilitation centers. The 196 family health teams cover approximately one million people in the Itaim Paulista, Itaquera, Tiradentes, Guaianases and São Miguel Paulista regions.

In 2012, the Santa Marcelina School of Medicine was created, adopting a curricular model which proposes the insertion of FCM and PHC from the first to the last semester of the course, with vertical integration, that is, between FCM modules, and transversal integration, that is, with the other subjects studied in the same semester.

\section{THE POLITICAL-PEDAGOGICAL PROJECT}

The Political-Pedagogical Project of the FASM, implemented in 2012, is based on the development of competencies established in the graduate profile according to the NCG for medical education defined by the Ministry of Education in 2001 and ratified in 2014.

The formulation of this project took place based on the teaching and assistance experience of the CSSM and the collaboration with the University of Toronto. Student exchange between the two institutions began in 2014 with the arrival of third-year Family Medicine (Global Health) residents for a sixmonth internship.
The partnership with the University of Toronto contributed to the FASM medical curriculum by means of five key points for medical training described by the Canadian College of Family Medicine. These points were reinforced, and also represent aspects that are central to the proposed NCG, with the curriculum underpinned by FCM and PHC: (1) ability to manage the clinical case; (2) ability to work in teams; (3) ability to communicate adequately with patients, family, and staff; (4) ability to practice evidence-based medicine; (5) development of actions to promote the health and well-being of the patient and the community.

\section{FCM AND PHC IN THE MEDICAL CURRICULUM OF THE FASM}

The educational model of FCM and PHC in the medical course is schematically represented in Table 1.

Meaningful learning models inspired this model, particularly described by Ausubel, in which contents of cognitive knowledge are constructed in a hierarchical way by superimposing broader concepts over less extensive concepts ${ }^{14}$. From the definition of fundamental concepts in FCM 1 to 4 , we add other complementary and more complex concepts, in the form of an upward spiral of knowledge. Thus, we try to create a

TABLE 1

FCM and PHC educational model from the first to sixth year of medical school

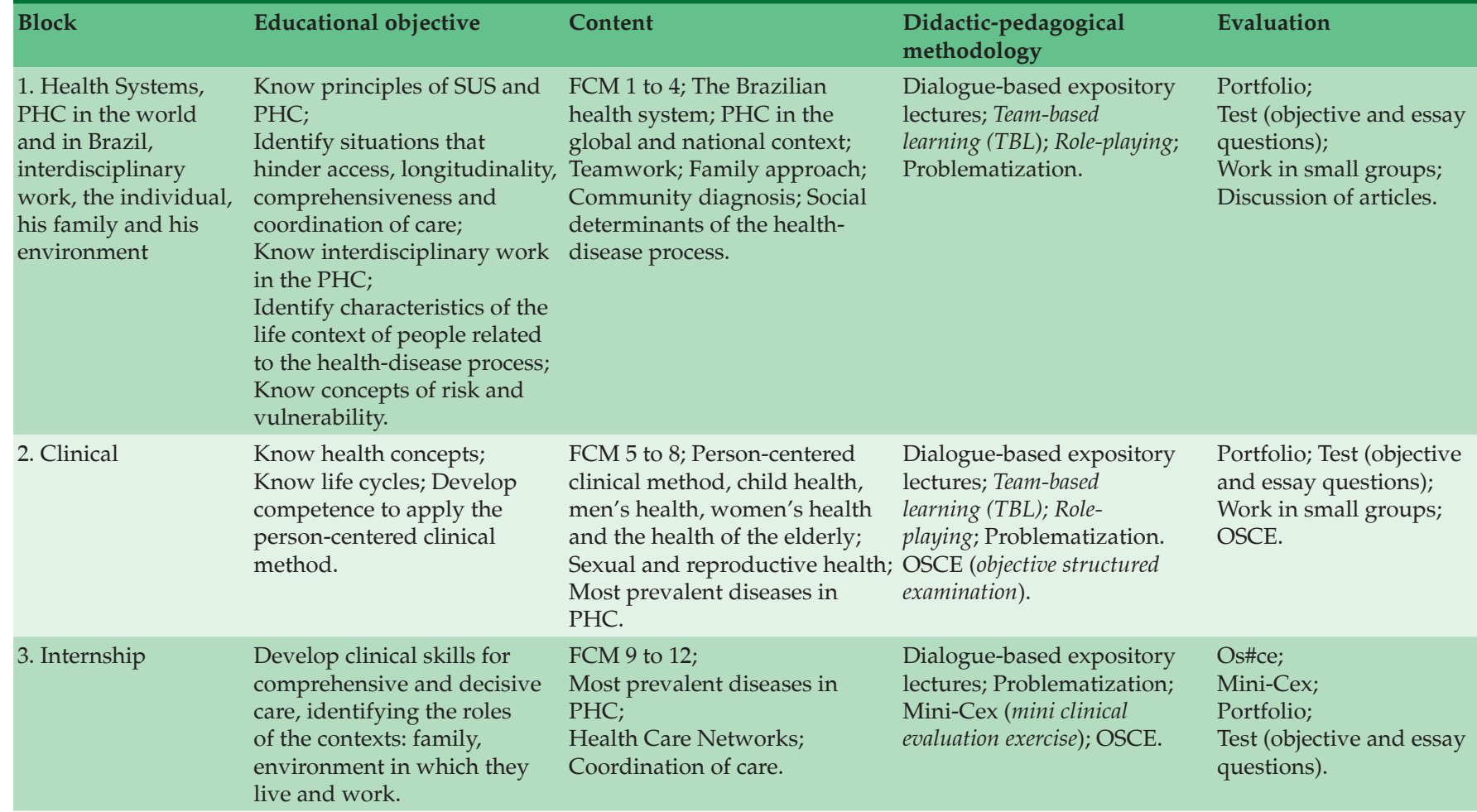


favorable scenario for the student to develop competences related to the area at the end of the medical course.

\section{Educational objectives}

The curricular proposal of the FASM establishes that at the end of the medical course the student should be able to: carry out a community diagnosis; conduct consultation using the personcentered clinical method; perform a family approach using light technologies, such as, genogram and ecomap; work in teams, knowing the skills of the professionals and proposing connections between the nuclei of knowledge; recognize the difficulties faced by users in the health system and propose actions to mitigate them; offer comprehensive and humanistic care, understanding the individual in relation to their life, family, social and environmental background.

In addition, the institution expects the graduate to understand the functioning of the health system, how primary, secondary and tertiary levels of care tie into each other; to be able to analyze problem situations that affect the efficiency of the system and impact on the quality of care offered to the population and be able to work out solutions to these situations.

\section{Program content}

As described in Table 1, the student's contact with the content of the area occurs in increasing degrees of complexity, knowledge, abilities and attitudes, by developing previous knowledge with new knowledge. Figure 1 describes the central theme of each module per semester of undergraduate training.

\section{Educational process planning}

The planning of each module is carried out in three stages: (1) the teachers responsible for the module construct the initial proposal considering the pedagogical objectives and the topics to be discussed, and propose the activities to be carried out during each visit to the BHU; (2) the proposal for each module is presented and debated by all FCM teachers; (3) a semiannual discussion forum is held with the purpose of articulating content and practices of the FCM modules with the disciplines of Epidemiology, Biostatistics, Semiology, Public Policy, and Spirituality and Thanatology.

The activities in the $\mathrm{BHU}$ are planned according to the competencies to be developed in each FCM module. A monthly meeting is held for the BHU preceptors and the

Figure 1

Family and Community Medicine Modules from the first to the twelfth semester of undergraduate training (FCM-FASM Educational Model)

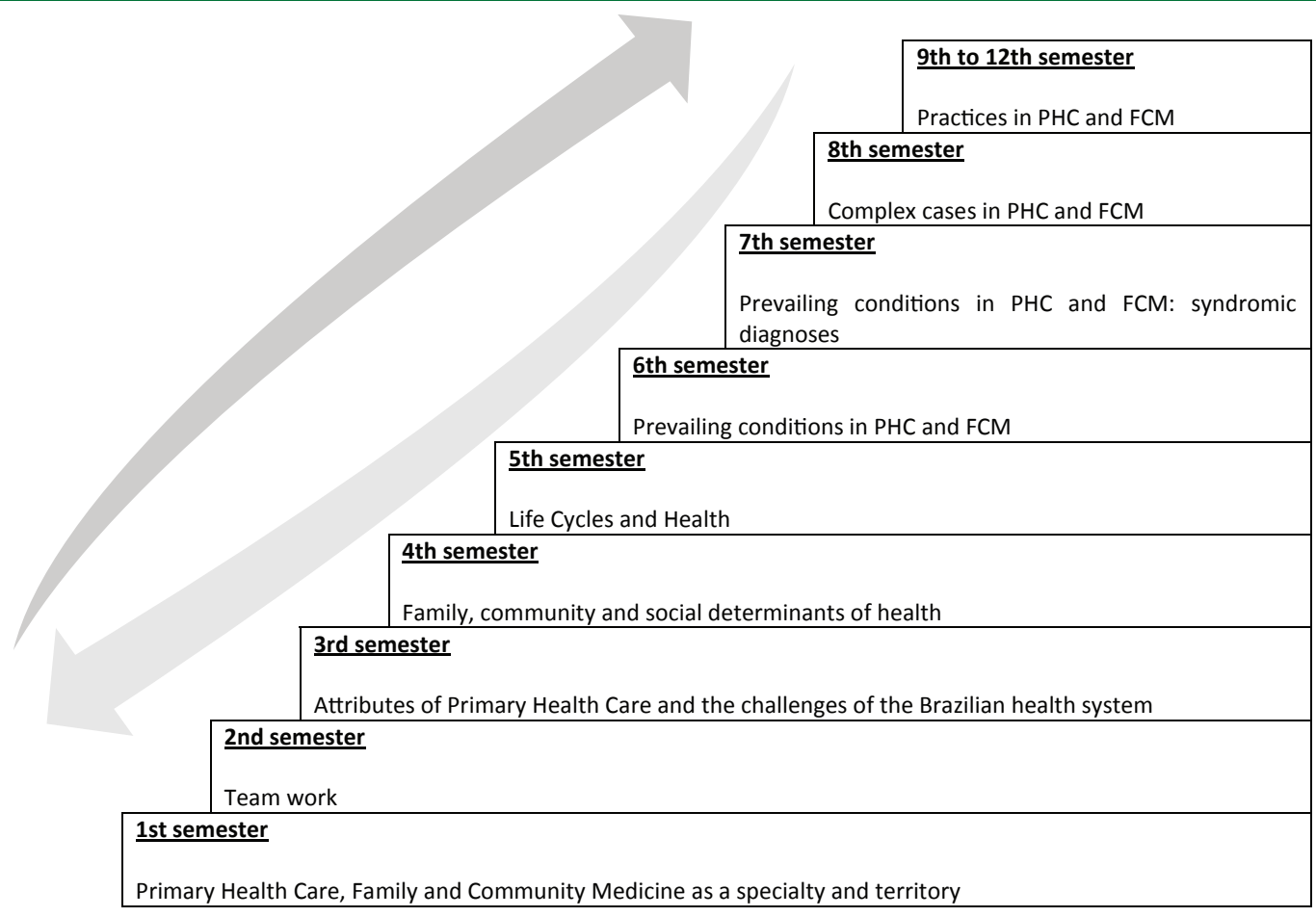


FCM teachers. The themes chosen for discussion emerge from two contexts: (1) practical difficulties experienced by preceptors in the BHU and (2) themes proposed by FASM teachers based on student feedback. Therefore, we created a space for the development, planning and evaluation of the theoretical and practical activities related to PHC and FCM, based on the local reality of PHC. This considered the difficulties faced by the preceptors in guaranteeing an adequate environment so that the educational process could occur in the best possible way, and the educational objectives and perspectives of the teaching-learning process proposed by the group of teachers. Furthermore, it is in this space that we discuss and devise strategies to overcome the difficulties faced by preceptors, such as meetings with managers, discussion of agendas and case discussion techniques, among others.

\section{Educational methodologies}

The following teaching-pedagogical strategies are used: expository dialogues, problematization, team-based learning, role-playing, simulated judgment, seminars, Mini-Cex, OSCE and work in small groups (Table 1). The choice of method is at the discretion of the teacher and his/her familiarity with the teaching methodologies, as long as it is in accordance with the educational objective and with the programmatic content envisaged.

It should be noted that FCM teachers come from family health teams, in addition to being BHU preceptors, prior to becoming teachers. Having work experience in FCM and PHC provides a grounding for teachers to develop encounters with students based on problem situations experienced in practice, linking the topic to be discussed with practical reality. This fact does not exempt the need to invest in teacher training, to prepare expositive dialogue classes for the development and application of the OSCE. Several studies have highlighted another relevant aspect: a good teacher is a good communicator, and an empathic and attitudinal model in any context ${ }^{15}$. Such characteristics are often present in FCM teachers, due to practical experience in their field of practice.

The following case exemplifies an educational activity designed for eighth-semester students (Table 2). It aims to stimulate the development of clinical, critical, ethical and humanized reasoning by articulating themes of the FCM modules from the first to the seventh semester and from the disciplines: Semiology, Epidemiology I and II, Teamwork, Evidence Based Medicine, Public Health Policies, Principles of SUS and PHC, and Spirituality and Thanatology. The case is presented to student groups, and the discussion is developed in two meetings.

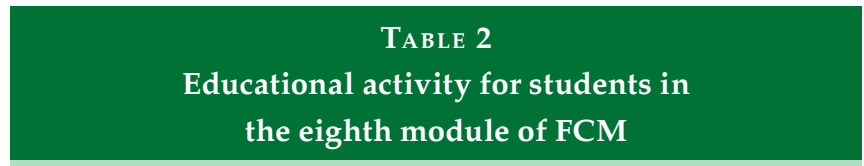

Scenario 1: Home visit to patient, Cíntia, by the community health agent, Márcia

Márcia: Good morning, Cíntia! How are you?

Cíntia: Hello, Marcinha! Well, everything is almost okay, there's only one thing that I only trust you to talk about ... it's a "problem down there".

Márcia: How long ago did it start?

Cíntia: Two weeks ago. I went to a healthcare service, and the doctor there prescribed an itch relief ointment. There was no time for an examination, there were too many people to attend to.

Márcia: Cíntia, let's do it this way: I'll talk to a doctor or nurse on the team and schedule an appointment for you today.

\section{Scenario 2: Basic Health Unit}

Dr. Ana: Good morning, Cíntia. Is everything all right? Márcia said that you wanted to talk to me...

Cíntia: Dr., I'm embarassed to talk about it... but it's a "problem down there" and I also wanted a medicine to avoid pregnancy. I tried to get it at the hospital, but the doctor said that his religion did not allow him to prescribe that type of medicine..

\section{First part (semiology, genogram, list of problems)}

If you were Dr. Ana, what questions would you ask Mrs. Cíntia?

Based on the information below, develop the genogram and list of individual and family problems.

Mrs. Cíntia (26 years old) complains of fights with her husband (Alberto), who complains about the lack of "sex". Mrs. Cíntia says she is tired of working (six hours a day in a telemarketing company and she still has to take care of her three children - Jessica, 3 years old, Marcos, 6 years old, and Paula, 9 years old). She reports that she had an abortion two years ago because her husband "did not want another child in the world".

Mr. Alberto has two older sisters and a younger brother, of whom he is very close. Mrs. Cíntia is very close to her mother and has little contact with her father, who left the family when she was three. The mother is in treatment for depression, which leaves Mrs. Cíntia very worried. Mrs. Cíntia has a younger brother from her mother's second marriage, with whom she has little contact since he lives in another city.

\section{Second part (Clinical and Epidemiology)}

From the characteristics of the lesion: what is your diagnostic hypothesis? (photograph)

Describe the possible stages of disease progression, if left untreated.

What exams are recommended for Cíntia? Why?

What is the treatment of choice?

What is Jarisch-Herxheimer's reaction? What should be done if it occurs?

What is counseling? Which team professionals should take counseling?

Discuss the concepts of risk and vulnerability in this case.

Is there is a need to fill out the notification form of the Information System on Diseases of Compulsory Declaration (SINAN)? 


\section{Third party (SUS, PHC and FHS)}

The trust relationship with CHA Márcia was essential to ensure full care. What aspects of PHC and characteristics of the FHS contribute to building the bond between the population and the team?

By not examining Cíntia and not guiding her as to how she could obtain contraceptive medication, which principles of the SUS were neglected by the doctor who attended her in the hospital?

\section{Part Four (Ethics and Humanization)}

Considering the Code of Medical Ethics and the principles of humanization, according to the National Policy:

Evaluate the behavior of the doctor in the hospital;

Discuss how assistance in the hospital could be improved.

(Dear reader, if you would like the answers to this case, send an $e$-mail to andreatenorio@usp.br)

\section{The evaluation process}

Evaluation by the students is carried out according to the proposals given by Perrenoud ${ }^{16}$, which are considered an integral part of the educational process and not restricted to the measurement of a lived process. In addition to being a way of evaluating student achievement, assessment is also an important pedagogical resource in the global educational process. According to our curricular proposal, diverse and combined methods characterize the evaluation process, with emphasis on the formative character. We opted for an evaluation processes that incorporated triangulation arrangements of combined techniques and instruments, such as theoretical tests, portfolios, Mini-Cex, OSCE, self-assessments and hetero-evaluations ${ }^{17}$.

\section{EDUCATIONAL MANAGEMENT}

The development of the educational process is determined by its management, which for FCM and PHC also involves organizational actions of the work processes in the BHU. These actions stand out as follows.

\section{Management and development of people}

Eighteen preceptors and nine FCM teachers are involved in the design and implementation of the educational process. Among them are the coordinators of the basic module, the clinical module, teaching-service integration and internship in FCM. Each group of four to five students accompanies a family health team. Currently, 18 teams receive the students.

The selection of preceptors is a key point in the educational process. A review of the literature on the Brazilian experience of preceptory practice in PHC points to a heterogeneity among physicians who assume this role ${ }^{18}$. In this context, it is necessary to establish criteria that favor the selection of pre- ceptors with a theoretical and practical capacity for teaching. This selection is made according to the following criteria: time of performance as FCM (at least two years), title of specialist or residence in FCM, experience as a preceptor and good relationship with the team.

Preceptors receive a scholarship from FASM according to the number of students and the phase of the course, and carry out various activities related to the school. The main idea is to promote closer ties between teaching and service, to increase team membership, to raise support and build proposals to deal with any difficulties. Thus, in addition to the monthly meeting, which aims to discuss the teaching-learning processes based on the local reality of the BHU and discuss strategies to address it, the preceptors participate in workshops on the teaching-learning process and case discussion workshops. They also engage in the construction and implementation of the of FASM's FCM academic projects - some of them are authors of several chapters of the Manual of the Family Physician (FASM), as well as being part of research projects linked to the Research Center in PHC and FCM.

Some strategies are used to improve communication among team members, such as the use of the Whatsapp application. This helps explain to team members the activity to be developed in the BHU in each FCM module each week. Hence, it enables planning of the activities linked to the themes discussed in the FCM module of the respective semester. Texts are sent via e-mail and Whatsapp regarding topics related, for example, to FCM, evidence-based medicine and medical education.

\section{Coordination with Santa Marcelina Hospital and Local Government}

The social organization responsible for the management of the $\mathrm{BHU}$ of the FHS in the neighborhoods of Itaquera, Tiradentes, Guaianases, Itaim Paulista and São Miguel is the Santa Marcelina Health Center. Two family physicians who are also part of the FASM faculty, work in the PHC coordination. Teachingservice integration has been pointed out in the literature as an important strategy for the human resource training for the SUS, taking into account the population's actual health needs ${ }^{19}$. In the case under study, it is observed that this connection reduces the dichotomy between the university environment and the local management context, as well as the distance between those who plan and those who execute the teaching activities. The participation of professionals in the theoretical construction of the teaching who are also inserted in the practical settings minimizes tensions between these two scenarios. These professionals are able to identify potential preceptors and the BHUs with the adequate resources to receive students. 
The training programs are designed in accordance with the Municipal Health Secretariat (MHS), initially by means of a request submitted by FASM for the PHC training program. The MHS establishes the necessary processes for formal regulation of these internships and their effective collaboration with the teaching activities and fundamental commitment to improve the care provided to the population served. The contract is renewed annually.

\section{CHALLENGES FACED}

The FCM and PHC disciplines in medical curricula are recent experiences that face challenges ranging from unfamiliarity and strangeness to lack of qualification in the field of action at the medical school itself. Furthermore, by their nature, they depend on health services that do not always favor the core activity of care and the educational objectives, such as inadequate physical installations and deteriorated environments.

Educational activities require procedures that are sometimes incompatible with the goals set in guiding documents management units, which makes challenging the legitimacy of professionals working in BHU as preceptors and teachers common work process that responds to the demand for care and the numerical target of consultations without hindering quality teaching. Agreement with the administrative bodies responsible for managing units in protected areas is necessary in terms of the doctor-preceptor agendas, and to promote professional recognition by the higher education institution's hiring, remuneration and teacher training within the framework of continuing education.

It is noteworthy that, as a developing field, there is a considerable shortage of qualified professionals for care and teaching. In the BHUs there are no doctors and preceptors with adequate training for their work. Investing in the preparation of these professionals is fundamental for their critical role and committment to the challenge of coordinating care and teaching. This process is sustained by recognition of the work and the sense of belonging to the group felt by those who lead the educational process, reducing the historical distance and prejudice according to which the academy is conceived and the service executed.

\section{FACILITATOR FACTS}

In the experience reported here, we record facilitating aspects largely responsible for the success achieved so far. The design of a medical course built on foundations which include solid training in FCM and PHC is perhaps the most powerful element for ensuring the effort for it to be taught and the consequent results. The political will of the formative apparatus is the singular starting point for this experience, which deserves to be highlighted. The care and teaching institution's history in the area is another success factor for service-school integration.

The proximity between the local BHU management and the preceptors and managers who are also teachers facilitates the dialogue required for didactic activities. Investment in the preceptor team management with conceptual and methodological alignment, and keeping teachers and preceptors informed about each activity with the use of different communication technologies, promote a feeling of belonging and constant support for everyone, favoring the execution of teaching activities.

A human resources policy that values and compensates teachers better also encourages adherence to the educational project.

\section{DISCUSSION}

Medical education has been debated on both a global and national level in the face of major changes in contemporary society and public health demands ${ }^{20}$. Technological, social and epidemiological transformations present challenges to the health area, while health, as a human right that must be guaranteed by the State, requires public policies that respond to this commitment. In this sense, PHC is a fundamental strategy for health care in several countries ${ }^{21}$, and the teaching of FCM, a guideline for medical training 5 .

However, developing physicians to respond to the demands of social needs beyond the boundaries of what brings prestige and social value to the doctor and, moreover, making it attractive for undergraduates to continue their training in this specialty represent arduous tasks for Brazilian medical schools. In Brazil, doctors are judged by the specialty they choose, the population segment they attend and the financial income they earn from their work. These values are present in the medical school and, along with offers on the medical labor market, determine the choice of specialty, reflecting the work conditions, workload, salary, recognition and social status ${ }^{22,23}$.

Concrete working conditions include physical areas, distances and technological resources. In the public sphere, service networks should also be contemplated, which should support the comprehensive health care model, a core principle of the SUS. However, the model of system regulation is applied heterogeneously and often insufficiently in the various regions of Brazil ${ }^{24}$.

Making FCM an attractive undergraduate specialty representing an effective choice medical residency, and responding to the social need for PHC physicians, involves, among other incentives, attractive careers and salaries, good training in FCM and PHC, and the provision of adequate service net- 
work settings in which the doctor can develop quality work that guarantees satisfaction with their professional choice.

Within this problem and focusing on medical training, we report here an educational experience that places FCM and PHC as strategic areas in the pedagogical project, with a strong institutional role. The curriculum of the FASM medicine course defined FCM and PHC as transversal axes of formation from the first to the last semester, integrating themes, disciplines, activities, teaching scenarios and seeking the construction of an institutional space to legitimize this area in the panorama of medical education. This can already be observed in the number of subjects engaged in it, through teachers, preceptors, specialists in other areas, in conjunction with other disciplines and service units, and in the creation of a research group focused on FCM and PHC. The organization of interdisciplinary integration seminars with the basic and professional cycle disciplines in which FCM acts as an agglutinating discipline and the collective production of a book on practice in this field are examples of its integrative and creative capacity within the curriculum.

Among the measures adopted with a view to teaching excellence, are: (1) the inclusion of first to fourth year students and medical interns in the BHU with the Family Health Strategy (FHS) and equipment in each team's territory, in order to develop competences for executing anamnesis and physical examination, formulate diagnostic hypotheses and develop therapeutic projects adapted to the local reality; (2) hiring family physicians to work as faculty members; (3) construction of interdisciplinary actions with epidemiology, health policies, spirituality and evidence-based medicine; (4) the use of problematizing methodologies in the teaching process, appropriate to the subject, the student profile and the teacher's expertise; (5) the use of preferably formative evaluations, with a variety of evaluation strategies as a resource for the development of competencies expected for each stage of the student; (6) pedagogical-assistance, improvement of teachers and preceptors through permanent education focused on the development of competencies for teaching in health; (7) discussion of topics such as health-disease process, territory, essential attributes and derivatives of PHC, individual and family and community approach, family physician in Brazil and the world, person-centered clinical method, evidence based medicine, medicine narrative, handling of more prevalent problems, coordination of care, acting with focus on integrality, development of knowledge, skills and attitudes necessary for a safe and decisive practice, understanding the home environment as a therapeutic setting for comprehensive clinical practice, according to the person-centered clinical record and ensuring safe registration, encouraging practices that sensitize the student to teamwork and interprofessional actions, and studying mechanisms to assess the quality of PHC work processes; (8) incentive for national and international exchange programs with undergraduate and residency programs in FCM, to improve and exchange experiences; (9) promotion of the publication of books, articles and research in PHC, prepared by teachers, preceptors and students.

For the preceptors, the efforts resulted in a sense of belonging to the teaching group and encouragement to settle in the BHU. In three years of undergraduate training, the turnover among preceptors is less than 15\%, while for other physicians in the local network it is about $40 \%$ per year. Once they feel stimulated to continue in their work posts, in line with doctor and teacher duties, the processes occur to ensure access management, comprehensive, longitudinal and coordinated care, which are the elementary premises of $\mathrm{PHC}^{25}$.

The set of concepts, methods and experiences being developed in the FASM medical curriculum, with emphasis on FCM and PHC, can bring elements to the current debate about how medical training engages in health issues in the contemporary world. This can be done with the firm purpose of collaborating to ensure the qualification of the SUS and PHC in the construction of a more equitable and socially just country, where health care is a guaranteed human right.

\section{REFERENCES}

1. Paim J, Travassos C, Almeida C, Bahia L, Macinko J. The Brazilian health system: history, advances, and challenges. Lancet 2011;377:1778-97.

2. Schmidt MI, Duncan BB, Silva GA, Menezes AM, Monteiro CA, Barreto SM et al. Chronic non-communicable diseases in Brazil: Burden and current challenges. Lancet 2011;377:1949-1961.

3. Brasil. Minitério da Educação. Diretrizes curriculares nacionais do curso de graduação em medicina 2001.[acesso em 12 abr 2016] Disponível em: http:/ / portal.mec.gov.br/ cne/arquivos/pdf/CES04.pdf.

4. Brasil. Ministério da Saúde. Projeto de Incentivo a Mudanças Curriculares nas Escolas de Medicina. [acesso em 23 jul 2016] Disponível em: http://portal.mec.gov.br/sesu/ arquivos/pdf/inc.pdf.

5. Brasil. Minitério da Educação. Diretrizes curriculares nacionais do curso de graduação em medicina 2014.[acesso em 9 jan 2016] Disponível em: http:/ / portal.mec.gov.br/index.php?option=com docman\&view =download \&alias $=15874-$ rces $003-$ $-14 \&$ Itemid $=30192$. 
6. Demarzo MMP, Almeida RCC, Marins JJN, Trindade TG, Anderson MIP, Stein AT et al. Diretrizes para o ensino na atenção primária à saúde na graduação em medicina. Rev Bras Educ Med 2012;36:143-148.

7. Conselho Federal de Medicina (Brasil). Radiografia das Escolas Médicas no Brasil. [acesso em 19 jan 2016] Disponível em: http://webpainel.cfm.org.br/QvAJA$\mathrm{XZf}$ /opendoc.htm?document=Radiografia do Ensino $\mathrm{m} \% \mathrm{C} 3 \%$ A9dico \%2FRadiografia doEnsino m\%C3\%A9dico. qvw\&host=QVS\%40scfm73\&anonymous=true.

8. Pagliosa FL, Ros MA. O relatório Flexner: para o bem e para o mal. Rev Bras Educ Med 2008;32:492-499.

9. Oliveira NA, Meirelles RMS, Cury GC, Alves LA. Mudanças Curriculares no Ensino Médico Brasileiro: um Debate Crucial no Contexto do Promed. Rev Bras Educ Med 2008;32:333-346.

10. Vieira JE, Elias PEM, Benseñor IJM, Grisi SJE. Instalação da disciplina de Atenção Básica em Saúde na Faculdade de Medicina da Universidade de São Paulo (2003-2006). Rev Bras Educ Med 2007;31:236-244.

11. Carvalho SR, Garcia RA, Rocha DC. O ensino da Saúde Coletiva no curso médico da Unicamp: experiências inovadoras junto a unidades básicas de saúde. Interface 2006;10: 457-472.

12. Brandão ERM, Rocha SV, Silva SS. Práticas de Integração Ensino-Serviço-Comunidade : Reorientando a Formação Médica. Rev Bras Educ Med 2013;37:573-577.

13. Alves HF. Vulnerabilidade socioambiental na metrópole paulistana: uma análise sociodemográfica das situações de sobreposição espacial de problemas e riscos sociais e ambientais. Rev Bras Est Pop 2006;23:43-59.

14. Ronca ACC. Teorias de ensino: a contribuição de David Ausubel. Temas em Psicol 1994;2: 91-95.

15. Costa NMD, Cardoso CG, Costa DC. Concepções sobre o bom professor de medicina. Rev Bras Educ Med 2012;36:499-505.

16. Perrenoud P. Avaliação: da excelência a regulação da aprendizagem entre as lógicas. 2ed. São Paulo: Artes Médicas;1999.

17. Macedo RS. Currículo, diversidade e equidade: luzes para uma educação intercrítica.1.ed. Salvador: EDUFBA; 2007.

18. Autonomo FROM, Hortale VA, Santos GB, Botti SHO. A Preceptoria na Formação Médica e Multiprofissional com Ênfase na Atenção Primária - Análise das Publicações Braisleiras. Rev Bras Educ Med 2015;39: 316-327.
19. Pizzinato A, Gustavo AS, Santos BRL, Ojeda BS, Ferreira E, Thiesen FV et al. A Integração Ensino-Serviço como Estratégia na Formação Profissional para o SUS. Rev Bras Educ Med 2012;36:170-177.

20. Rios IC. Subjetividade contemporânea na educação médica: a formação humanística em medicina. São Paulo. Tese [Doutorado em Ciências] - Universidade de São Paulo; 2010.

21. Organização Mundial da Saúde. Primary Health Care: now more than ever. Geneva: WHO; 2008.

22. Cruz JAS, Sandy NS, Vannuchi TR, Gouveia EM, Passerotti CC, Bruschini H, Srougi M. Fatores determinantes para a escolha da especialidade médica no Brasil. Rev Med (São Paulo 2010;89(1):32-42.

23. Lefevre JH, Roupret M, Kerneis S, Karila L. Career choices of medical students: a national survey of 1780 students. Med Educ 2010;44:603-612.

24. Mendes EV. 25 anos do Sistema Único de Saúde: resultados e desafios. Estud Avançados 2013;27(78):27-34.

25. Starfield B. Is primary care essential? Lancet 1994;344:11291133.

\section{CONTRIBUTION OF AUTHORS}

Andréa Tenório Correia da Silva: conception of the manuscript, writing of the main text, analysis and discussion of the data and revision of the text. Martim Elviro de Medeiros Junior: elaboration of the main text, analysis and discussion of the findings. Paulo de Nogueira Fontão: elaboration of the main text and revision. Haraldo Cesar Saletti Filho: elaboration of the main text and revision. Pedro Félix Vital Junior: elaboration of the main text and analysis of the data. Monique Marie Marthe Bourget: elaboration of the main text and revision. Izabel Cristina Rios: conception of the manuscript, main text writing and final review.

\section{CONFLICT OF INTERESTS}

Nonexistent

\section{MAILING ADDRESS}

Andréa Tenório Correia da Silva

Faculdade Santa Marcelina - Medicina de Família

e Comunidade

Rua Cachoeira Utupanema, 40

Itaquera - São Paulo

CEP08270-140-SP

E-mail: andreatenorio@usp.br 